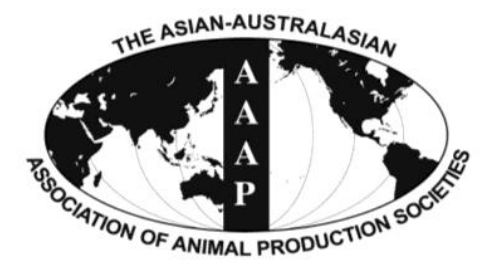

Asian-Aust. J. Anim. Sci.

Vol. 25, No. $3: 421$ - 427

March 2012

www.ajas.info

http://dx.doi.org/10.5713/ajas.2011.11240

\title{
Cloning and Molecular Characterization of Porcine $\beta$-casein Gene (CNS2)
}

\author{
Sang Mi Lee, Hye-Min Kim, Seung Ju Moon and Man-Jong Kang* \\ Department of Animal Science, Chonnam National University, Gwangju 500-757, Korea
}

\begin{abstract}
The production of therapeutic proteins from transgenic animals is one of the most important successes of animal biotechnology. Milk is presently the most mature system for production of therapeutic proteins from a transgenic animal. Specifically, $\beta$-casein is a major component of cow, goat and sheep milk, and its promoter has been used to regulate the expression of transgenic genes in the mammary gland of transgenic animals. Here, we cloned the porcine $\beta$-casein gene and analyzed the transcriptional activity of the promoter and intron 1 region of the porcine $\beta$-casein gene. Sequence inspection of the $5^{\prime}$-flanking region revealed potential DNA elements including SRY, CdxA, AML-a, GATA-3, GATA-1 and C/EBP $\beta$. In addition, the first intron of the porcine $\beta$-casein gene contained the transcriptional enhancers Oct-1, SRY, YY1, C/EBP $\beta$, and AP-1, as well as the retroviral TATA box. We estimated the transcriptional activity for the 5'-proximal region with or without intron 1 of the porcine $\beta$-casein gene in HC11 cells stimulated with lactogenic hormones. High transcriptional activity was obtained for the 5'-proximal region with intron 1 of the porcine $\beta$-casein gene. The $\beta$-casein gene containing the mutant TATA box (CATAAAA) was also cloned from another individual pig. Promoter activity of the luciferase vector containing the mutant TATA box was weaker than the same vector containing the normal TATA box. Taken together, these findings suggest that the transcription of porcine $\beta$-casein gene is regulated by lactogenic hormone via intron 1 and promoter containing a mutant TATA box (CATAAAA) has poor porcine $\beta$-casein gene activity. (Key Words : Lactogenic Hormones, HC11 Cells, TATA Box, Milk Protein, Porcine Casein Gene)
\end{abstract}

\section{INTRODUCTION}

The milk of transgenic animals has the potential for use as a bioreactor to product useful recombinant proteins or bioactive substances (Clark, 1998; Houdebine, 2009). Casein, which is one of the major components of milk proteins, includes calcium-sensitive caseins $(\alpha \mathrm{S} 1-, \beta-$, and $\alpha$-S2-casein) and $\kappa$-casein (Rosen et al., 1999; Rijnkels, 2001). Casein genes expressed in the mammary gland during lactation and are regulated by a variety of factors including steroid hormones, peptides, cell-cell and cellextracellular matrix interactions (Doppler et al., 1989; Boudreau et al., 1995; Rosen et al., 1999). $\beta$-casein is a major component of cow, goat and sheep milk and its promoter has been used to regulate the expression of transgenic genes in the mammary gland of transgenic animals (Clark, 1998). $\beta$-casein is an abundant milk protein expressed in mammary epithelial cells during lactation. In

\footnotetext{
* Corresponding Author : M. J. Kang. Tel : +82-62-530-2113, Fax : +82-62-530-2129, E-mail : mjkang@ chonnam.ac.kr Submitted Jul. 23, 2011; Accepted Oct. 5, 2011; Revised Nov. 3, 2011
}

mammary epithelial cell lines, expression of $\beta$-casein depends on the synergistic action of insulin, glucocorticoid and prolactin (Doppler et al., 1989). Since $\beta$-casein promoter is regulated by the lactogenic hormone during lactation, the $\beta$-casein promoter has often been used for the generation of transgenic animals that produce proteins with mammary gland specific expression (Chang et al., 2010). The production of therapeutic proteins using transgenic pig is one of the most important and significant successes of animal biotechnology because pig has some advantage such as a short gestation and large litter size (Wheeler and Walters, 2001).

Bovine $\beta$-casein cDNA has been identified and found to consist of a 672 nucleotide coding region (Baev et al., 1987). $\beta$-casein is the major casein in bovine milk, accounting for as much as $30 \%$ of its total protein mass. The porcine $\beta$-casein cDNA sequence consists of a 696-bp open reading frame and encodes a protein of 232 amino acids in length (Alexander and Beattie, 1992). The bovine $\beta$-casein gene spans at least $8.5 \mathrm{~kb}$ and encodes 9 exons (Gorodetsky et al., 1988). Expression of the $\beta$-casein milk 
protein gene has been shown to be regulated by the addition of glucocorticoid and prolactin hormones in the murine mammary epithelial cell line, HC11 (Schmitt-Ney et al., 1991). The gene regulatory DNA sequences recognized by transcription factors are conserved in the promoters of different casein genes from several species (Mercier and Viloite, 1993; Rosen et al., 1999). However, transcriptional enhancer elements present in the intron increase the basal activity of the $\beta$-casein promoter. In addition, these intronic enhancer elements augment the induction of $\beta$-casein promoter by lactogenic hormones (Kolb, 2003). Casein cDNA and genomic DNA of many species have been isolated and characterized by molecular cloning. However, porcine $\beta$-casein genomic DNA has not yet been isolated or characterized.

In the present study, we describe the exon/intron organization of the porcine $\beta$-casein gene. We also analyzed the transcription unit of the porcine $\beta$-casein gene in the mouse mammary epithelial cell line, HC11. We demonstrated that the first intron of the porcine $\beta$-casein gene contains a transcriptional promoter/enhancer sequence and that lactogenic expression of the porcine $\beta$-casein gene was probably regulated by the first intron. Moreover, we found that porcine $\beta$-casein genes promoters containing a mutant TATA box (CATAAAA) have poor promoter activity.

\section{MATERIALS AND METHODS}

\section{Cloning of porcine $\boldsymbol{\beta}$-casein gene by long PCR}

Porcine genomic DNA was extracted from the ear tissues of three-way crossbreds (LWD) obtained at the slaughterhouse. LA-PCR (Long and Accurate PCR) was conducted to identify the porcine $\beta$-casein genomic DNA as follows using primers prepared based on the porcine $\beta$-casein promoter region (Accession No. AY452035) reported to the NCBI and the result of cDNA analysis. The primers for PCR were as follows; porcine $\beta$-casein promoter sense primer (CCCACTATTTCCTGATTCTTGA TTAACTTT), exon 6 antisense primer (TGTTGTTCCT CCCGCTTTAGCTTCTCAATT), exon 2 sense primer (GACTTGATCGCCATGAAGCTCCTCATCCTT) and exon 9 antisense primer (GCCTAAGGATTAATTTATTG AAATGACTGG). PCR was conducted using $100 \mathrm{ng}$ of the genomic DNA extracted from porcine ear tissues with 10 pmol of sense and antisense primers, $0.5 \mathrm{U}$ i-Max II DNA polymerase (Intron, Korea), $1 \times \mathrm{PCR}$ buffer and $200 \mu \mathrm{M}$ dNTP mixture as follows: $2 \mathrm{~min}$ of initial denaturation at $94^{\circ} \mathrm{C}$ followed by 30 cycles of $94^{\circ} \mathrm{C}$ for $30 \mathrm{~s}, 63^{\circ} \mathrm{C}$ for 30 seconds, $72^{\circ} \mathrm{C}$ for $7 \mathrm{~min}$ and $30 \mathrm{~s}$, followed by a final elongation step at $72^{\circ} \mathrm{C}$ for $15 \mathrm{~min}$. The PCR products were confirmed by electrophoresis on $0.8 \%$ agarose gel, after which they were cloned into the pGEM T-easy vector
(Promega, USA). Sequencing was conducted using an ABI PRISM 377 sequencer. The nucleotide sequence was analyzed by Genetyx-win (version 4.0).

\section{Construction of luciferase vector}

To test for promoter activity, the 5'-flanking region containing promoter with and without intron 1 was fused to the firefly luciferase gene in pGV-B2 (TOYO INK MFG, Japan) as follows. For construction of luciferase vector containing only promoter $(-2,657$ to +39$)$ of porcine $\beta$ casein gene, PCR was conducted using porcine $\beta$-casein 5 , arm DNA containing normal TATA or mutant TATA box as a template. A sense primer (CCCACTATTTCCTGATT CTTGATTAACTTT) and antisense primer (CTCGAGTCC AAAGTGGAGGACAAGAAGTGA) containing the XhoI restriction enzyme site were designed for ligation in the multi cloning site of $\mathrm{pGV}-\mathrm{B} 2$ vector. PCR was conducted using $10 \mathrm{pg}$ of DNA and $10 \mathrm{pmol}$ of sense and antisense primers, $1 \times \mathrm{PCR}$ buffer, 0.5 unit of i-MaxII polymerase (Intron, Korea) and $200 \mu \mathrm{M}$ of dNTP mixture. PCR was conducted under the following conditions: $2 \mathrm{~min}$ of initial denaturation at $94^{\circ} \mathrm{C}$, followed by 35 cycles of $94^{\circ} \mathrm{C}$ for 30 $\mathrm{s}, 62^{\circ} \mathrm{C}$ for $30 \mathrm{~s}, 72^{\circ} \mathrm{C}$ for $4 \mathrm{~min}$ and a final elongation step at $72^{\circ} \mathrm{C}$ for $15 \mathrm{~min}$. PCR products were ligated with pGEM T-easy vector to generate pGEM- $\beta$-Promoter plasmid (Promega, USA). Inserts were prepared by digestion of pGEM- $\beta$-Promoter plasmid with EcoRV and XhoI restriction enzyme. pGV-B2 vector was prepared by digestion of the SmaI and XhoI restriction sites, after which it was ligated with an insert containing normal TATA or mutant TATA box from pGEM- $\beta$-Promoter plasmid (denoted $\mathrm{p} \beta$ CE1TATA and $\mathrm{p} \beta$ CE1mTATA, respectively). For construction of luciferase vector containing promoter and intron $1(-2,657$ to $+2,450)$ of porcine $\beta$-casein, PCR was conducted using porcine $\beta$-casein $5^{\prime}$ arm DNA containing normal TATA or mutant TATA box as a template. For cloning in pGV-B2 vector, sense primer (CCCACTA TTTCCTGATTCTTGATTAACTTT) and antisense primer (CCATGGCGATCAAGTCCTGTGAATGGGGAA)

containing the NcoI restriction enzyme site were designed. PCR was conducted with $10 \mathrm{pg}$ of DNA using $10 \mathrm{pmol}$ of sense and antisense primers, $1 \times \mathrm{PCR}$ buffer, 0.5 unit of i-MaxII polymerase (Intron, Korea) and $200 \mu \mathrm{M}$ of dNTP mixture. PCR was conducted under the following conditions: $2 \mathrm{~min}$ of initial denaturation at $94^{\circ} \mathrm{C}$ followed by 35 cycles of $94^{\circ} \mathrm{C}$ for $30 \mathrm{~s}, 62^{\circ} \mathrm{C}$ for $30 \mathrm{~s}$, and $72^{\circ} \mathrm{C}$ for 5 min, with a final elongation step at $72^{\circ} \mathrm{C}$ for $15 \mathrm{~min}$. PCR products were ligated with pGEM T-easy vector to generate pGEM- $\beta$-intron1 plasmid (Promega, USA). Inserts were prepared by digestion of pGEM- $\beta$-intron1 plasmid with SmaI and NcoI restriction enzyme. Inserts were subcloned into the vector $\mathrm{pGV}-\mathrm{B} 2$ to generate $\mathrm{p} \beta \mathrm{CE} 2 \mathrm{TATA}$ and 
$\mathrm{p} \beta$ CE2mTATA luciferase vector.

\section{DNA transfection}

For luciferase vector transfection, pCMV $\beta$-galactosidase plasmid (Clontech, USA) was used for normalization. Transfection was conducted as follows. HC11 cells were inoculated on a 96 well plate at a density of $1 \times 10^{4}$ cells and the culture medium was replaced with fresh medium the next day. The cells were then transfected using jetPEI transfection reagent (Polyplus-transfection, France) according to the manufacturer's instruction. Luciferase vector $(0.05 \mathrm{pmol})$ and $\mathrm{pCMV}-\beta$-gal plasmid $(0.02 \mathrm{pmol})$ were used. In the transfection experiment, parallel plates of cells were transfected with pGVB2 and pGV-P2, which served as negative and positive controls, respectively. The plasmid pGV-B2 lacks a eukaryotic promoter; therefore, no luciferase activity was detected in cells transfected with pGV-B2. The plasmid pGV-P2 contains the SV40 early promoter, which drives expression of the luciferase gene. The transfection efficiency was assayed by co-transfection with the $\beta$-galactosidase reporter, pCMV $\beta$-gal.

\section{Lactogeneic hormonal induction of $\mathrm{HC11}$ cells}

After the transfection, cells were cultured for $24 \mathrm{~h}$. The culture medium was replaced with serum free medium for 48 hours with hormone treatment. Hormone treatment was conducted using $5 \mu \mathrm{g} / \mathrm{ml}$ insulin (Sigma, USA), $1 \mu \mathrm{M}$ dexamethasone (Sigma, USA), and $5 \mu \mathrm{g} / \mathrm{ml}$ prolactin (Sigma, USA) in serum free RPMI 1640 (HyClone, USA) for 48 hours. The negative control was not treated with hormones.

\section{Firefly luciferase assays}

After hormone treatment for 48 hours, the cells were washed two times with $1 \times$ PBS and then lysis buffer $(50 \mu \mathrm{l})$ was added into cells. The cell lysates were transferred to 1.5 $\mathrm{ml}$ tubes. After collection, cells were immediately put into the liquid nitrogen. Frozen cells were then thawed at $37^{\circ} \mathrm{C}$ and centrifuged at $12,000 \mathrm{rpm}$ and $4^{\circ} \mathrm{C}$ for $2 \mathrm{~min}$, after which the supernatant was collected. For measurement of the luciferase activity, $20 \mu \mathrm{l}$ supernatant and $50 \mu \mathrm{l}$ of Luciferase Assay System with Reporter Lysis Buffer (Promega, USA) were added to a 96 well plate and analyzed using a GloMax 96 microplate Luminometer with single reagent injector (Promega, USA) according to manufacturer's instructions. The transfection efficiency was determined by co-transfection with the $\beta$-galactosidase reporter, pCMV $\beta$-gal. $\beta$-galactosidase activity was measured using a chemiluminescence assay kit (Promega, USA) according to the manufacturer's instructions. The relative light units were calculated by normalizing the firefly luciferase activity against the $\beta$-galactosidase activity to evaluate the transfection activity.

\section{RESULTS}

\section{Cloning and molecular characterization of porcine $\beta$-casein gene}

To identify the $\beta$-casein gene in porcine cells, LA-PCR was conducted using two pairs of $\beta$-casein specific primers and porcine genomic DNA as template. PCR products containing promoter-exon 6 and exons 2-9 were amplified with $6.8 \mathrm{~kb}$ and $5.5 \mathrm{~kb}$ (data not shown). Figure 1 summarizes the genomic organization of the porcine $\beta$-casein gene. Exon 1 encoded the 5'-UTR, while exon 2 contained the translational initiator codon AUG. Exon 8 contained the translation termination codon and exon 9 contained the 3'-UTR. The sequence reported in this paper has been deposited in the GenBank database under accession no. EU242520.

All intron/exon splice junctions conformed to the GT/AG rule. As shown in Table 1, exon 1 was 45 bp, exon 2 was $63 \mathrm{bp}$, exon 3 was $27 \mathrm{bp}$, exon 4 was $27 \mathrm{bp}$, exon 5 was $24 \mathrm{bp}$, exon 6 was $45 \mathrm{bp}$, exon 7 was $519 \mathrm{bp}$, exon 8 was $42 \mathrm{bp}$, and exon 9 was $306 \mathrm{bp}$. With the exception of exon 7 and exon 9, all other exons very short. Additionally, intron 1 was $2,398 \mathrm{bp}$, intron 2 was $735 \mathrm{bp}$, intron 3 was $118 \mathrm{bp}$, intron 4 was $1,325 \mathrm{bp}$, intron 5 was $94 \mathrm{bp}$, intron 6

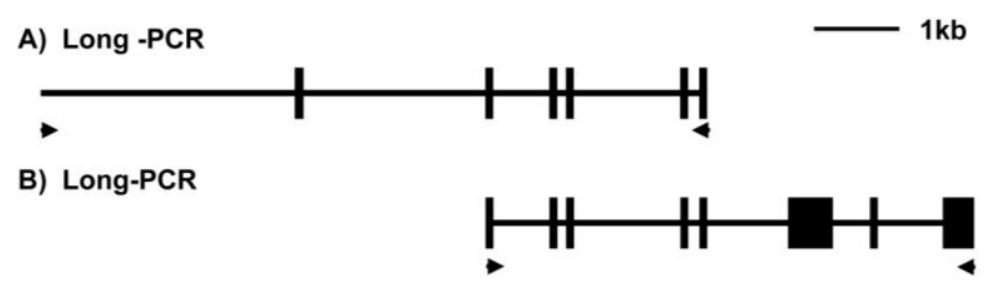

C) $\beta$ - casein genome (11.5kb)

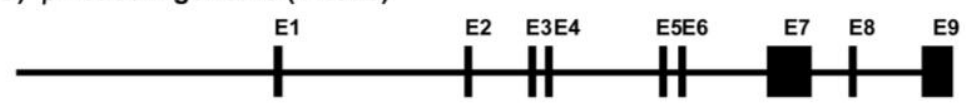

Figure 1. Schematic diagram of overlapping PCR products encoding the porcine $\beta$-casein gene. Exons are indicated by numbers and closed boxes. Arrows indicate PCR primer. 
Table 1. Exon/intron organization of the porcine $\beta$-casein gene

\begin{tabular}{|c|c|c|c|c|}
\hline \multirow{2}{*}{$\begin{array}{l}\text { Exon } \\
\text { No. }\end{array}$} & \multirow{2}{*}{$\begin{array}{c}\text { Exon } \\
\text { size (bp) }\end{array}$} & \multicolumn{2}{|c|}{ Sequence at exon-intron junction } & \multirow{2}{*}{ Intron length } \\
\hline & & 5' splice donor & 3' Splice acceptor & \\
\hline 1 & 45 & GGA GAA AAG gtaagaattt & ccattcacag GAC TTG ATC & 2,398 \\
\hline \multirow[t]{2}{*}{2} & 63 & GCA AGA GCG gtaagtacag & ttctctatag AAG GAA GAA & 735 \\
\hline & & A $\quad \mathrm{R} \quad \mathrm{A}$ & $\begin{array}{lll}K & \mathrm{E} & \mathrm{E}\end{array}$ & \\
\hline \multirow[t]{2}{*}{3} & 27 & TCT GGT GAG gtaagatatt & tccttttcag ACT GTG GAA & 118 \\
\hline & & $\begin{array}{lll}\mathrm{S} & \mathrm{G} & \mathrm{E}\end{array}$ & $\begin{array}{lll}\mathrm{T} & \mathrm{V} & \mathrm{E}\end{array}$ & \\
\hline \multirow[t]{2}{*}{4} & 27 & AGC AGT GAG gtaagccaat & ttttctaaag GAA TCT ATT & 1,325 \\
\hline & & $\begin{array}{lll}S & S & E\end{array}$ & $\begin{array}{lll}\mathrm{E} & \mathrm{S} & \mathrm{I}\end{array}$ & \\
\hline \multirow[t]{2}{*}{5} & 24 & ATC AGC AAG gtaaagactt & tgttttctag GAG AAA ATT & 94 \\
\hline & & $\begin{array}{lll}\mathrm{I} & \mathrm{S} & \mathrm{K}\end{array}$ & $\begin{array}{llll} & \mathrm{E} & \mathrm{K} & \mathrm{I}\end{array}$ & \\
\hline \multirow[t]{2}{*}{6} & 45 & CAA ACA GAG gtaatttgtt & ttctttccag GAT GAA CGC & 1,307 \\
\hline & & $\begin{array}{lll}\mathrm{Q} & \mathrm{T} & \mathrm{E}\end{array}$ & $\begin{array}{lll}D & E & R\end{array}$ & \\
\hline \multirow[t]{2}{*}{7} & 519 & TAC AAC CCT gtaagtccaa & aatttttaag GTC TAA GAG & 606 \\
\hline & & $\begin{array}{lll}\mathrm{Y} & \mathrm{N} & \mathrm{P}\end{array}$ & $\mathrm{V}$ & \\
\hline 8 & 42 & TCA CTT TTG gtaagcttta & tattccgcag AAT TGA CTG & 784 \\
\hline 9 & 305 & & & \\
\hline
\end{tabular}

was $1,307 \mathrm{bp}$, intron 7 was $606 \mathrm{bp}$, and intron 8 was $734 \mathrm{bp}$. identified $\beta$-casein region containing the promoter was These results confirmed that the $\beta$-casein genome $11,517 \mathrm{bp}$. Furthermore, we were isolated the $\beta$-casein gene comprising exon 1 - exon 9 was 8,410 bp in length. The containing the mutant TATA box (CATAAAA) by LA-PCR promoter region was 3,107 bp, so the entire length of the of samples from another individual pig (Figure 2A).

A)

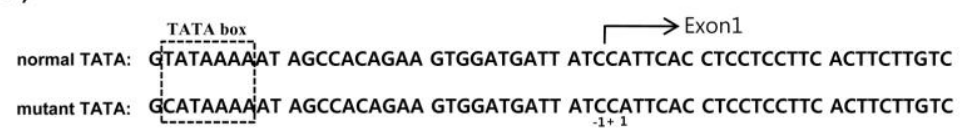

B)

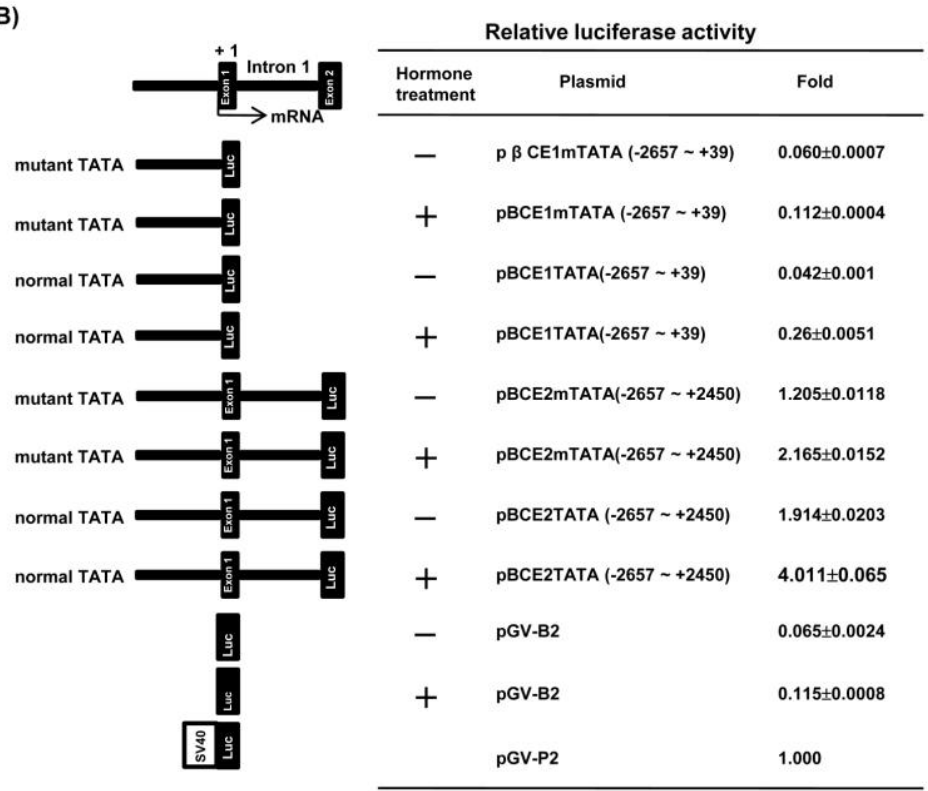

Figure 2. Analysis of the promoter activity. (A) Nucleotide sequence of the porcine $\beta$-casein promoter containing the normal and mutant TATA box. (B) Functional promoter activity of the 5 '-flanking region of the porcine $\beta$-casein gene fused to the firefly luciferase reporter gene. Each chimeric gene was cotransfected with the pCMV $\beta$-galactosidase plasmid into HC11 cells, and then assayed for firefly luciferase and $\beta$-galactosidase activities as described in the material and methods. Firefly luciferase activity in each individual experiment was corrected for variations in transfection efficiency by normalizing the value against the $\beta$-galactosidase activity in the same extract. The normalized activity of each promoter was then expressed relative to that of pGV-P2, with pGV-P2 assigned a relative activity of 1.0. The data represent the mean of triple transfection experiments for each plasmid. 
Functional analysis of the 5 '-flanking region of the porcine beta-casein gene

To determine the transcriptional activity of the 5'proximal region and intron 1 of the porcine $\beta$-casein gene in HC 11 cells by lactogenic hormones, the genomic DNA fragments containing the 5 '-flanking region $-2,657$ to +39 ( $\mathrm{p} \beta$ CE1TATA) and $-2,657$ to $+2,450$ containing intron 1 ( $\beta$ CE2TATA) were fused to the luciferase gene $\mathrm{pGV}-\mathrm{B} 2$. Moreover, the luciferase vectors were constructed from genomic DNA containing mutant TATA with the 5'-flanking region $-2,657$ to $+39(\mathrm{p} \beta$ CE1mTATA $)$ and $-2,657$ to $+2,450$ containing intron 1 (p $\beta$ CE2mTATA) to validate the necessity of the normal or mutant TATA box in the promoter for expression of the $\beta$-casein gene.

The luciferase activity of the $\mathrm{p} \beta$ CE1TATA and $\mathrm{p} \beta$ CE1mTATA without intron 1 were very low when compared with the positive control pGV-P2. The luciferase activity of $\mathrm{p} \beta$ CE1TATA and $\mathrm{p} \beta$ CE1mTATA were 0.042 and 0.06 , respectively. However, when lactogenic hormone was added, the luciferase activity of $\mathrm{p} \beta$ CE1TATA and $\mathrm{p} \beta$ CE1mTATA were 0.26 and 0.112 , respectively. Moreover, the luciferase activity of $\mathrm{p} \beta \mathrm{CE}$ 1TATA was increased when compared with $\mathrm{p} \beta \mathrm{CE} 1 \mathrm{mTATA}$ in the hormone treatment or non-treatment group. $\mathrm{p} \beta \mathrm{CE} 2 \mathrm{mTATA}$ and $\mathrm{p} \beta \mathrm{CE} 2 \mathrm{TATA}$ containing intron 1 of the porcine $\beta$-casein gene showed remarkably high luciferase activity when compared with $\mathrm{p} \beta$ CE1TATA and $\mathrm{p} \beta$ CE1mTATA without intron 1 in the hormone treatment or non treatment group. A high luciferase activity (4.011) was obtained from $\mathrm{p} \beta$ CE2TATA subjected to lactogenic hormone treatment (Figure 2B).

Figure 3 and 4 show the nucleotide sequence of the 5'flanking region and intron 1 of the porcine $\beta$-casein gene. A computer-assisted search for the putative promoter/ enhancer element (set at a cutoff score of $>90 \%$ ) was conducted using TFSEARCH (http://mbs.cbrc.jp/research/ db/TFSEARCH.html). A typical TATA box was present at -32 and potential sites of C/EBP $\beta$ (CCAAT/EnhancerBinding Protein $\beta$ ) are present at $-1,846$ and $-2,110$ (data not shown). The 5 ' flanking region of the porcine $\beta$-casein gene also contained DNA motifs for SRY, CdxA, AML-a, GATA-3, and GATA-1. In addition, the first intron of the porcine $\beta$-casein gene contained transcriptional enhancer Oct-1, SRY, YY1, C/EBP $\beta$, AP-1, and the retroviral TATA box.

\section{DISCUSSION}

In this study, the porcine $\beta$-casein gene was identified by long PCR. This porcine $\beta$-casein gene consisted of nine exons and eight introns and was $11.57 \mathrm{kbp}$ long, including its promoter. Comparison of the organization of the bovine and mouse $\beta$-casein genes, the porcine $\beta$-casein gene had the similar exon/intron organization with other species (Mercier and Viloite, 1993). In addition, the porcine $\beta$-casein gene containing the mutant TATA box (CATAAAA) was cloned from another individual pig. In this $\beta$-casein gene, which contained the mutant TATA box, the first Thymine was substituted with Cytosine.

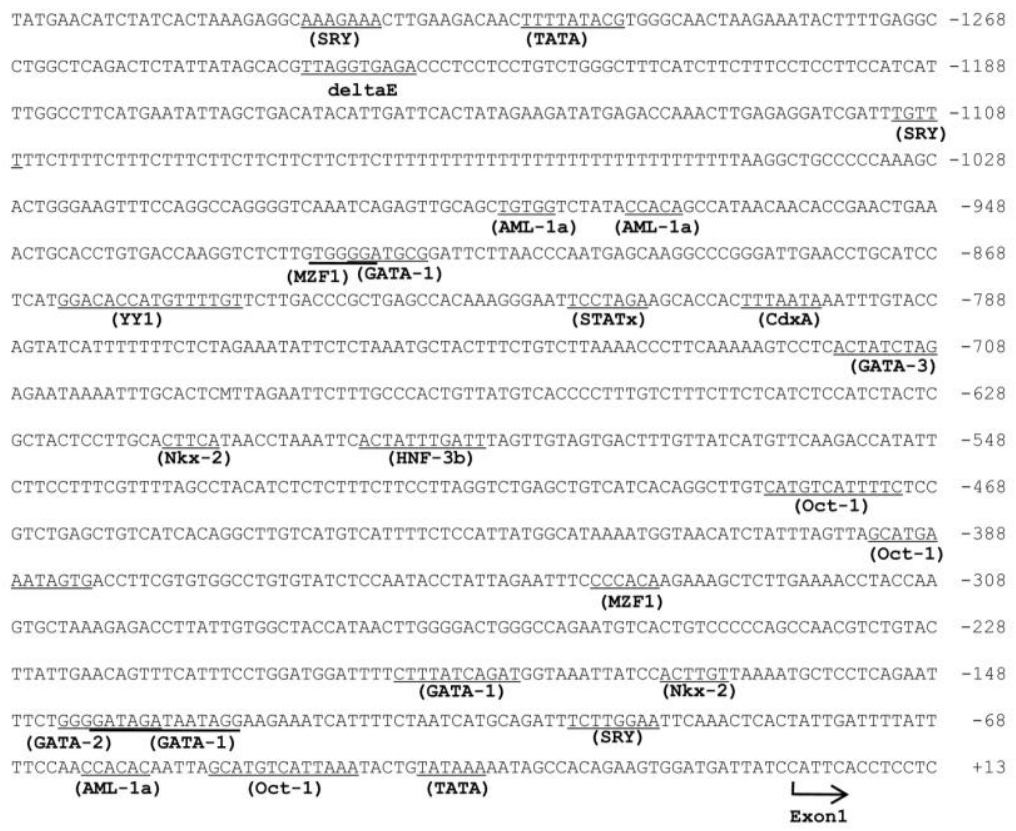

Figure 3. Nucleotide sequence of the 5 '-flanking region of the porcine $\beta$-casein gene. The residues preceding it are indicated by a negative number. Arrow below the sequence indicates the transcription start site. Potential binding sites for transcription factors $(>90 \%$ cutoff score) are underlined. Sequence information is available under GenBank Accession number EU242520. 


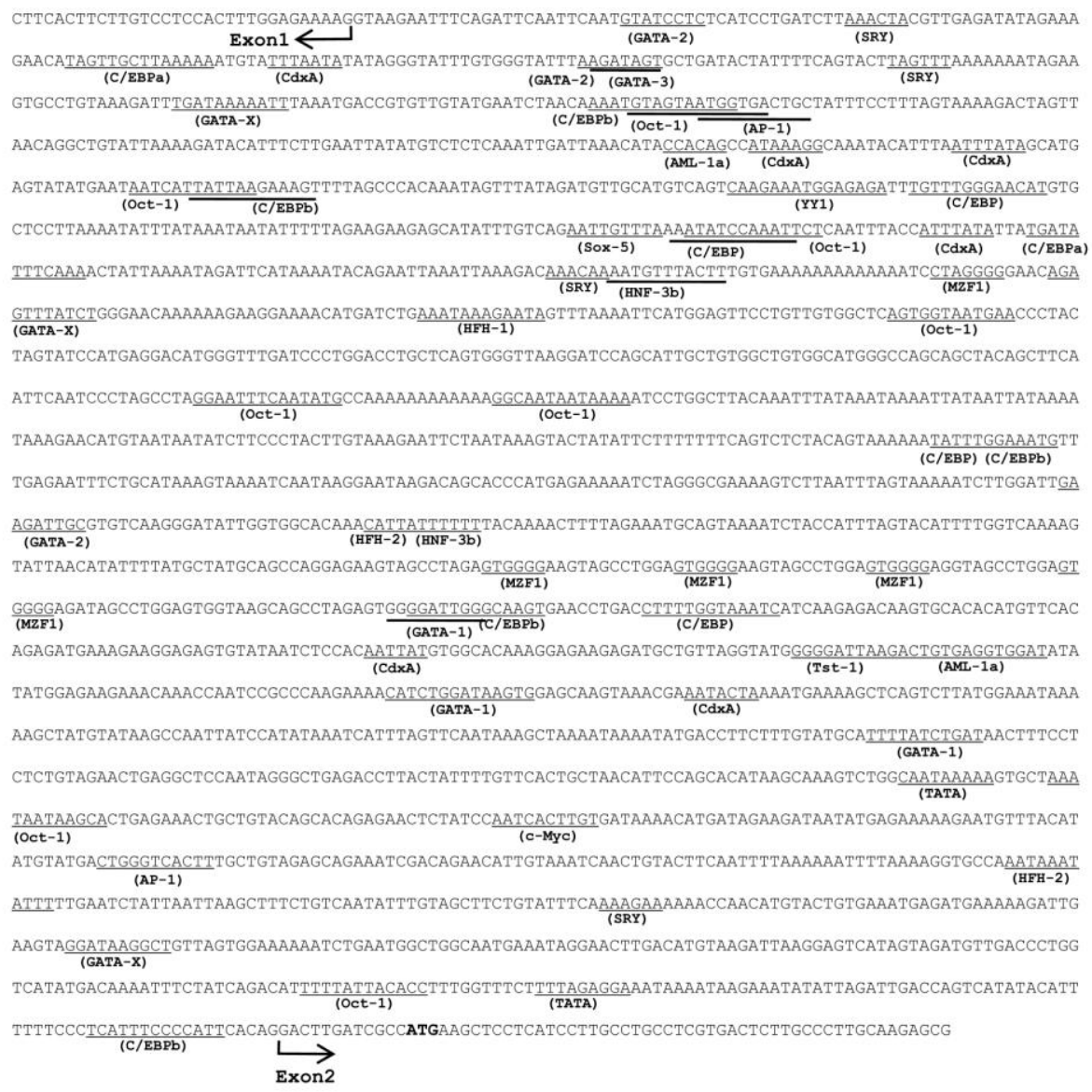

Figure 4. Nucleotide sequence of intron 1 of the porcine $\beta$-casein gene. Potential binding sites for transcription factors ( $>90 \%$ cutoff score) are underlined. Sequence information is available under GenBank Accession number EU242520.

Caseins are major milk proteins that account for nearly $80 \%$ of the proteins in milk. Milk contains several caseins, as1-, as2-, $\beta$ - and $\kappa$-casein, which are encoded by independent genes (Doppler et al., 1989; Rosen et al., 1999). Transcription of the casein gene in mammary epithelial cells is regulated by the lactogenic hormones, insulin, glucocorticoids, and prolactin. The synergistic action of glucocorticoid and prolactin hormones on the rat and pig $\beta$-casein promoter has been examined in the murine mammary epithelial cell line, HC11 (Doppler et al., 1989; Boudreau et al., 1995; Rosen et al., 1999; Lee et al. 2008).

Functional analysis of the 5'-flanking region of the porcine $\beta$-casein gene was conducted in $\mathrm{HC} 11$ cells using the genomic DNA fragment containing the 5'-flanking region $-2,657$ to +39 and $-2,657$ to $+2,450$, which includes intron 1 in the $\beta$-casein gene containing mutant TATA and normal TATA. In the $\beta$-casein gene containing the normal TATA box, the luciferase activity of the 5'-flanking region containing intron $1(-2,657$ to $+2,450)$ by lactogenic hormone treatment was 15 fold higher than that of the 5 'flanking region not containing intron $1(-2,657$ to +39$)$. Our results are consistent with previous data, which suggests that expression of the $\beta$-casein gene is regulated by lactogenic signals via intron 1 (Kolb, 2003; Lee et al., 2008). Moreover, the luciferase activity of the 5'-flanking region containing the mutant TATA box in the promoter region was lower than that of the 5 '-flanking region containing the normal TATA box. It was previously reported that the TATA box in the vasopressin and $\beta$-globin gene have a deviant CATAAAA box (Xu et al., 1991; Ho and Murphy, 2002). These mutant TATA boxes have also been shown to elicit relatively weak promoter activity (Xu et al., 1991; Ho and Murphy, 2002). The results of the present study indicate that the TATA box in the promoter region plays an important role in expression of the $\beta$-casein gene.

The 5 'flanking region of the porcine $\beta$-casein gene also contained DNA motifs for SRY, CdxA, AML-a, GATA-3, GATA-1, and C/EBP $\alpha$. However, the GR, AP-1, STAT5 and YY-1 DNA motifs were not found in this region of the porcine $\beta$-casein gene. The first intron of the porcine $\beta$-casein gene contained the putative Oct-1, SRY, YY1, $\mathrm{C} / \mathrm{EBP} \beta, \mathrm{AP}-1$, and retroviral TATA box.

The glucocorticoid receptor (GR), AP-1 (fos/jun dimer), STAT5 and YY-1 (Ying Yang-1) have been implicated in 
$\beta$-casein gene expression in mice and humans (Mercier and Viloite, 1993; Rosen et al., 1999). However, these DNA motifs were not found in the 5'-flanking region of the porcine $\beta$-casein gene. It has previously been reported that the first intron of the mouse and bovine $\beta$-casein gene contains enhancer elements (Kang et al., 1998; Kolb, 2003). The first intron of the mouse $\beta$-casein gene contains putative GR, YY1, C/EBP, Oct-1, AP-1 and TATA box (Kolb, 2003). In this study, the first intron of the porcine $\beta$-casein gene contained the transcriptional enhancers Oct-1, SRY, YY1, C/EBP $\beta$, and AP-1, and the retroviral TATA box. However, the DNA motif of the glucocorticoid receptor was not found in the first intron of the $\beta$-casein gene. These potential sites may be required for basal transcription and regulation of the porcine $\beta$-casein gene by the lactogenic hormone.

Here, we demonstrated that the first intron of the porcine $\beta$-casein gene contains a transcriptional promoter/ enhancer sequence and that lactogenic expression of the porcine $\beta$-casein gene was probably regulated by the first intron. However, the mutant TATA box (CATAAAA) in the porcine $\beta$-casein gene has weak promoter activity. Further studies are required to elucidate the actual nature and regulation of the porcine $\beta$-casein gene. Thus, these data can serve as a foundation for mammary gland-specific expression of foreign genes in gene targeting pigs.

\section{ACKNOWLEDGEMENTS}

This study was supported by a grant (Code 20070101034009 and \#PJ008172) from the BioGreen 21 Program, Rural Development Administration, Republic of Korea.

\section{REFERENCES}

Alexander, L. J. and C. W. Beattie. 1992. The sequence of porcine beta-casein cDNA. Anim. Genet. 23:369-371.

Baev, A. A., I. K. Smirnov and S. I. Gorodetskiǐ. 1987. Primary structure of cDNA for bovine beta-casein. Mol. Biol. 21:255265.

Boudreau, N., C. Myers and M. J. Bissell. 1995. From laminin to lamin: Regulation of tissue-specific gene expression by the ECM. Trends Cell Biol. 5:1-4.
Chang, M., J. W. Lee, D. B. Koo, S. T. Shin and Y. M. Han. 2010. Knocking-in of the human thrombopoietin gene on beta-casein locus in bovine fibroblasts. Asian-Aust. J. Anim. Sci. 23:806813.

Clark, A. J. 1998. The mammary gland as a bioreactor: expression, processing, and production of recombinant proteins. J. Mammary Gland Biol. Neoplasia 3:337-350.

Doppler, W., B. Groner and R. K. Ball. 1989. Prolactin and glucocorticoid hormones synergistically induce expression of transfected rat beta-casein gene promoter constructs in a mammary epithelial cell line. Proc. Natl. Acad. Sci. USA. 86:104-108.

Gorodetsky, S. I., T. M. Tkach and T. V. Kapelinskaya. 1988. Isolation and characterization of the Bos taurus beta-casein gene. Gene 66:87-96.

Ho, M. Y. and D. Murphy. 2002. The vasopressin gene noncanonical Hogness box: effect on protein binding and promoter function. Mol. Cell. Endocrinol. 186:17-25.

Houdebine, L. M. 2009. Production of pharmaceutical proteins by transgenic animals. Comp. Immunol. Microbiol. Infect. Dis. 32:107-121.

Kang, Y. K., C. S. Lee, A. S. Chung and K. K. Lee. 1998. Prolactin-inducible enhancer activity of the first intron of the bovine beta-casein gene. Mol. Cells 30:259-265.

Kolb, A. 2003. The first intron of the murine $\beta$-casein gene contains a functional promoter. Biochem. Biophys. Res. Commun. 306:1099-1105.

Lee, P., H. K. Chung, H. G. Lee, H. C. Lee, J. S. Woo, S. Lee, S. J. Jo, W. K. Chang, H. T. Lee, M. Kwon and J. K. Park. 2008. Cloning and characterization of 5 '-untranslated region of porcine beta casein gene (CSN2). Domest. Anim. Endocrinol. 35:245-253.

Mercier, J. C. and J. L. Viloite. 1993. Structure and function of milk protein genes. J. Dairy Sci. 76:3079-3098.

Rijnkels, M. 2002. Multispecies comparison of the casein gene loci and evolution of casein gene family. J. Mammary Gland Biol. Neoplasia 7:327-345.

Rosen, J. M., S. L. Wyszomierski and D. Hadsell. 1999. Regulation of milk protein gene expression. Annu. Rev. Nutr. 19:407-436.

Schmitt-Ney, M., W. Doppler, R. K. Ball and B. Groner. 1991. Beta-casein gene promoter activity is regulated by the hormone-mediated relief of transcriptional repression and a mammary-gland-specific nuclear factor. Mol. Cell Biol. 11:3745-3755.

Wheeler, M. B. and E. M. Walters. 2001. Transgenic technology and application in swine. Theriogenology 56:1345-1369.

Xu, L. C., M. Thali and W. Schaffner. 1991. Upstream box/TATA box order is the major determinant of the direction of transcription. Nucleic Acids Res. 19:6699-6704. 